\title{
Protein oxidation under extremely low frequency electric field in guinea pigs. Effect of $\mathrm{N}$-acetyl-L-cysteine treatment
}

\author{
Göknur Güler', Zerrin Türközer², Elcin Ozgur¹, Arin Tomruk ${ }^{1}$, Nesrin Seyhan ${ }^{1}$ \\ and Çimen Karasu ${ }^{3}$ \\ ${ }^{1}$ Gazi Non-Ionizing Radiation Protection Center, Department of Biophysics, Faculty of Medicine, Gazi University, 06500 \\ Ankara, Turkey \\ ${ }^{2}$ Department of Biochemistry, Faculty of Medicine, Gazi University, 06500 Ankara, Turkey \\ ${ }^{3}$ Department of Medical Pharmacology, Faculty of Medicine, Gazi University, 06500 Ankara, Turkey
}

\begin{abstract}
Modern age exposes humans to an increasing level of electromagnetic activity in their environment due to overhead power lines and transformers around residential areas. Studies have shown that treatment with antioxidants can suppress the oxidative damage induced by electromagnetic fields in various frequencies of the non-ionizing radiation band. In this study, we detected protein carbonyl content (PCO), advanced oxidation protein products (AOPP) in liver and 3-nitrotyrosine (3-NT) levels in plasma of guinea pigs in order to investigate the effects of N-acetyl-L-cysteine (NAC) administration on oxidative protein damage induced by power frequency electric (E) field $(50 \mathrm{~Hz}$, $12 \mathrm{kV} / \mathrm{m}, 7$ days $/ 8 \mathrm{~h} /$ day). We also analyzed hepatic hydroxyproline level to study protein synthesis. According to the findings of the present study, no statistically significant changes occurred in PCO, AOPP and 3-NT levels of the guinea pigs that were exposed to the E field with respect to the control group. However, liver hydroxyproline level was significantly diminished in the E field exposure group compared to the control and PCO, hydroxyproline and 3-NT levels changed significantly in the NAC-administrated groups.
\end{abstract}

Key words: Electric field - N-acetyl-L-cysteine - Protein carbonyl content - 3-nitrotyrosine - Advanced oxidized protein products - Hydroxyproline

\section{Introduction}

Due to increasing use of electricity in modern society, nonionizing electromagnetic field (EMF) sources, such as power lines and other extremely low frequency (ELF) sources are becoming ubiquitous and indispensable components of the spectrum of the human environment. In a comparison of all electrical technologies, power lines contribute strikingly high proportions to the composition of environmental EMF. For instance, the electric (E) field level ranges from $1 \mathrm{kV} / \mathrm{m}$ at maximum height $(20 \mathrm{~m})$ to as much as $12 \mathrm{kV} / \mathrm{m}$ at minimal cord height $(13 \mathrm{~m})$ for a power line of $750 \mathrm{kV}$ (Grandolfo and Vecchia 1985).

Correspondence to: Çimen Karasu, Department of Medical Pharmacology, Faculty of Medicine, Gazi University, 06500 Ankara, Turkey E-mail:karasu@gazi.edu.tr
During last quarter of the twentieth century, public and scientific interest focused on possible risks on biological systems related to ELF EMF exposure that result from sources such as power lines. Studies of EMF exposure on cells have determined that some macromolecules are susceptible to EMF and may differentiate their activities within cells upon frequency, strength and duration of EMF exposure (Blank 1995).

It is well established that secondary chemical messengers, namely free radicals, function in the induction of the cellular responses upon EMF exposure. Therefore, several investigations were performed on free radical production and antioxidant system of the tissues and blood samples under the effects of magnetic fields (Lupke et al. 2004; Zmyslony et al. 2004; Bediz et al. 2006; Simko et al. 2006) and E fields (Harakawa et al. 2005; Güler et al. 2006, Güler et al. 2007). Free radicals target structural molecules such as lipids, proteins and nucleic acids. Proteins and amino acids are 
defined as major targets for free radical attacks and oxidative damage since they constitute a large proportion of cell and tissue composition (Stadtman and Levine 2003; Cumaoglu et al. 2007). Due to its charged structure, collagen has been frequently studied under EMF (Seyhan and Canseven 2006; Seyhan and Güler 2006), since it can be directed trough applied E field (Marino et al. 1983). In order to determine their protectiveness against oxidative damage induced by EMF exposure, investigations under EMF in various frequencies of non-ionizing radiation band have included studies of the antioxidants such as vitamin $\mathrm{C}$ and $\mathrm{E}$ (Oral et al. 2006), caffeic acid phenethyl ester and melatonin (Oktem et al. 2005; Ozguner et al. 2005a,b, 2006) and ginkgo biloba (Ilhan et al. 2004) treated as nutrition.

Oxidative damage often induces loss of specific protein functions involved in the regulation of cell structure, signaling and various enzymatic processes of the cell such as metabolism. Free radical attacks on proteins can covalently modify amino acid residues resulting in the formation of a variety of intermediates and products, such as protein carbonyl content (PCO), advanced oxidation protein products (AOPP) and 3-nitrotyrosine (3-NT, tyrosine nitration). Oxidation by reactive oxygen species (ROS) produces carbonyl groups (aldehydes and ketones) on amino acid side chains, especially of proline, arginine, lysine and threonine. The usage of PCOs as a marker provides some advantages due to their early formation and their relative stability compared to the other oxidation products. Oxidized proteins are degraded by cells within hours and days while lipid peroxidation products are removed within minutes (DalleDonne et al. 2003). Various investigators (Alderman et al. 2002; Cakatay et al. 2003) have focused their attention to the AOPP that are formed during oxidative stress by the action of chlorinated oxidants, mainly hypochlorous acid and chloramines (produced by myeloperoxidase in activated neutrophiles) (Pan et al. 2008). AOPP are also defined as dityrosines containing cross-linked protein products, which are considered reliable markers for estimating the degree of oxidant-mediated protein damage (Alderman et al. 2002). In addition to ROS-mediated protein modification, reactive nitrogen species (RNS) derived from nitric oxide (NO) can also alter protein function, protein turn-over and influence immune responses leading to protein modifications (Zobalı et al. 2001). Tyrosine nitrosylation, which reflects nitrosative stress, leads to protein damage through another molecular mechanism.

Combination of superoxide anion $\left(\mathrm{O}_{2}{ }^{-}\right)$and $\mathrm{NO}$ generates peroxynitrite $\left(\mathrm{ONOO}^{-}\right)$, which is a cytotoxic species implicated in both the origin and the progression of protein oxidation (Stadtman and Levine 2000). $\mathrm{ONOO}^{-}$attack on proteins causes nitration of the ortho position of tyrosine leading to the production of 3-NT, which has been considered a specific marker for the de- tection of protein damage mediated by $\mathrm{ONOO}^{-}$in vivo (Halliwell 1997).

As a novel approach, we investigated attacks of free radicals on proteins by means of detecting $\mathrm{PCO}, \mathrm{AOPP}$, and 3-NT under the effect of $50 \mathrm{~Hz}$ E fields. Concurrent with the application of E field, we also administered N-acetyl-Lcysteine (NAC), a popular antioxidant and a scavenger of oxygen-derived free radicals, in order to explain if it acts as antioxidant, reduce oxidative damage or as pro-oxidant in tissue medium.

In this study, we investigated the effects of $50 \mathrm{~Hz} 12$ $\mathrm{kV} / \mathrm{m}$ E fields on hepatic carbonyl and AOPP levels, as well as the 3-NT level of the plasma alongside the administration of NAC. We also assessed the hydroxyproline level in liver homogenates so that we could estimate the difference that occurs in collagen levels after the application of both $\mathrm{E}$ field and NAC.

\section{Materials and Methods}

\section{Animals}

The experimental protocol was reviewed and approved by the Laboratory Animal Care Committee of Gazi University. All the animal procedures were performed in accordance with the approved protocol. A total of eighty old male guinea pigs (approximately 14 week), weighing 250-300 g, were obtained from Dr. Refik Saydam Hygiene Center (Turkey). The animals were adapted for 2 weeks to the laboratory conditions before the experiment.

Since placing more than one animal in a cage would create a stress factor, a single animal was placed in each cage during each E field exposure period. All the animals were kept at room temperature $\left(23^{\circ} \mathrm{C}\right)$ and a relative humidity was $50 \%$, their day and night cycle was set up as $12 \mathrm{~h}$ and they were fed ad libitum on a standard lab chow and carrot.

\section{E field exposure system}

E fields were applied to guinea pigs in wooden cages with dimensions of $80 \times 80 \times 18 \mathrm{~cm}$. For vertical field exposure circuit copper plates were mounted on the top and the bottom faces of the cages. The copper plate spacing was $18 \mathrm{~cm}$ and the dimensions of the plates were $80 \times 80 \times 0.2 \mathrm{~cm}$. The positive terminal of the power supply was always connected to the upper plate and the negative terminal to the lower plate. Electric potentials were applied to the copper plates mounted on the wooden boxes to produce $50 \mathrm{~Hz}$ E fields with a magnitude of $12 \mathrm{kV} / \mathrm{m}$. The arrangement was chosen for keeping the distance between the copper plates small with respect to their dimensions in order to generate homogeneous $\mathrm{E}$ field in the exposure space. The magnitude of the 


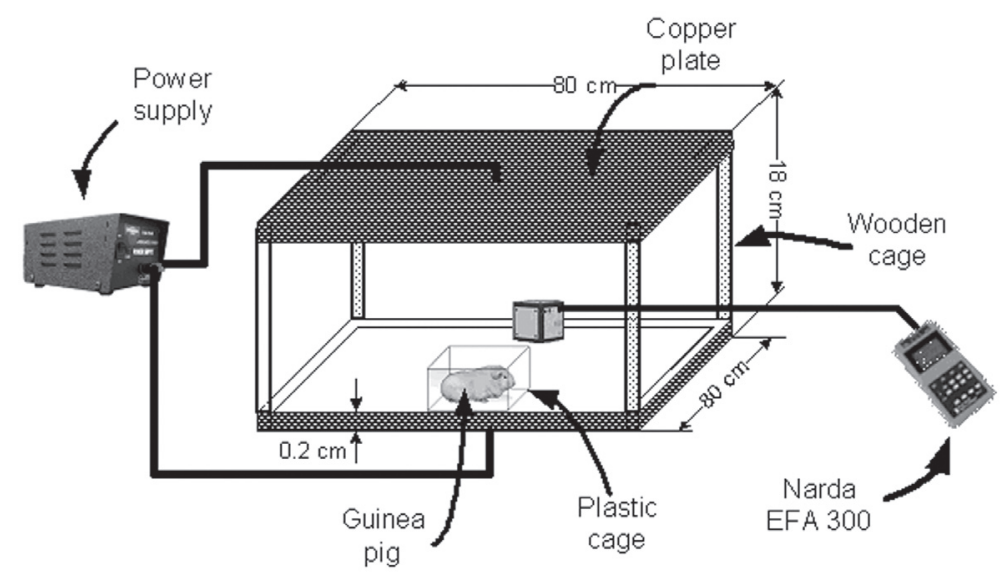

Figure 1. Vertical electric field experimental setup.

E field in the cages of guinea pigs was determined not only by theoretical calculation, but also by measurements using a NARDA EFA-300 E field probe (Figure 1).

\section{Experimental design}

A total of forty male guinea pigs were randomly divided into four groups composed of 10 guinea pigs each for groups.

Group I (control): $1 \mathrm{ml}$ isotonic saline solution was injected intraperitoneally (i.p.) in order to prevent the occurrence of stress from injection daily for seven consecutive days and each guinea pigs was kept in a plexiglass cage under experimental setup, but E field exposure device was off.

Group II (E field exposure): guinea pigs exposed to E field were injected $1 \mathrm{ml}$ isotonic saline solution i.p. $30 \mathrm{~min}$ before the daily exposure period for seven consecutive days.

Group III (NAC): NAC (300 mg/kg) was injected i.p. into the right extremity of animals daily for seven consecutive days and guinea pigs were kept in plexiglass cage under experimental setup, but E field exposure device was off.

Group IV (NAC + E field exposure): the guinea pigs were exposed to E field, for seven consecutive days and NAC (300 $\mathrm{mg} / \mathrm{kg}$ ) was injected i.p. daily into the right extremity of the guinea pigs for $30 \mathrm{~min}$ before $\mathrm{E}$ field exposure.

One week exposure period for $8 \mathrm{~h}$ daily was conducted for each exposure group (Group II and Group IV). The E field exposure period was from 9 a.m. to 5 p.m. After the last exposure day, the guinea pigs were anesthetized by the injection of ketamine $(40 \mathrm{mg} / \mathrm{kg}$ administered intramuscular, i.m.) and xylazine (10 mg/kg administered i.m.). The guinea pigs were killed by decapitation. Afterwards, liver tissues were obtained very quickly for biochemical analysis; the specimens were washed out from contaminating blood with ice-cold saline buffer, and stored at $-85^{\circ} \mathrm{C}$.
Determination of hydroxyproline levels in liver tissue

Method known as "ISO 3496" (1997, Meat and Meat Products - Determination of Hydroxyproline Content, International Organization for Standardization) involves getting the hydroxyproline of the hydrolysis of the sample after homogenization (Disperser T10 basic D-79219; IKAWERKE, GmbH, Staufer) and measuring the optical density of the color formed by the addition of sulphuric acid at $\mathrm{pH}$ 6.6 and wavelength $\lambda=558 \mathrm{~nm}$ (UV-1601 Shimadzu spectrophotometer; Kyoto, Japan). Hydroxyproline contents of the tissue samples were determined using the standard curves for samples containing known concentrations of hydroxyproline (H-1637 product, Sigma). Two samples were taken from each homogenized tissue, and the concentrations measured by spectrometry were averaged.

\section{Determination of PCO levels in liver tissue}

We followed the method described by Levine et al. (1990) with slight modifications. Briefly, $1 \mathrm{ml}$ of liver homogenates were divided equally, namely $50 \%$ of homogenates separated into one tube as "test" and another tube as "control". Protein in the liver tissues was precipitated by the addition of $20 \%$ trichloracetic acid (TCA) (w/v). Precipitated protein was collected by centrifugation at $3000 \times g($ Mikro 22/22R; Hettich-Zentrifugen GmbH\&Co., Tuttlingen, Germany). The supernatant was carefully aspirated and discarded. $0.5 \mathrm{ml}$ of $10 \mathrm{mmol} / 1$ 2.4-dinitrophenylhydrazine (DNPH) prepared in $2.5 \mathrm{~mol} / \mathrm{l}$ hydrochloric acid $(\mathrm{HCl})$ was added to the test sample and $0.5 \mathrm{ml}$ of $2.5 \mathrm{~mol} / \mathrm{l} \mathrm{HCl}$ alone was added to the control sample. The contents were mixed thoroughly and incubated in the dark at room temperature for $1 \mathrm{~h}$. The tubes were shaken intermittently every $10 \mathrm{~min}$. Then $0.5 \mathrm{ml}$ of $20 \%$ TCA (w/v) was added to both tubes and 
the mixture. The tubes were then centrifuged at $11,000 \times g$ for $3 \mathrm{~min}$ to obtain the protein pellet. The supernatant was carefully aspirated and discarded. Finally the precipitates were washed three times with $1 \mathrm{ml}$ of ethanol : ethyl acetate $(1: 1, \mathrm{v} / \mathrm{v})$ to remove unreacted DNPH and lipid remnants. The final protein pellet was dissolved in $0.6 \mathrm{ml}$ of $6 \mathrm{~mol} / \mathrm{l}$ guanidine hydrochloride and incubated at $37^{\circ} \mathrm{C}$ for 10 min. Guanidine was adjusted to $\mathrm{pH} 2.3$ with $\mathrm{HCl}$ instead of trifluoroacetic acid used by Levine et al. (1990) and this constituted the slight modification previously mentioned. The insoluble materials were removed by centrifugation at $4000 \times g$. Carbonyl content was determined by taking the spectra of the representative samples at 355-390 nm. Each sample was red against the control sample (treated with $2.5 \mathrm{~mol} / \mathrm{l} \mathrm{HCl}$ ). The carbonyl content was calculated from peak absorption ( $370 \mathrm{~nm}$ ) using an absorption coefficient of $22,000(\mathrm{~mol} / \mathrm{l})^{-1} \cdot \mathrm{cm}^{-1}$. PCO was expressed as nanomole per milligram of protein. The protein content was determined by the method of Lowry et al. (1951) using bovine serum albumin as standard. Protein levels in the samples were prepared in a concentration of $1 \mathrm{mg} / \mathrm{ml}$. As the samples were $0.5 \mathrm{ml}$, results were obtained by multiplying the data by two.

\section{Determination of AOPP levels in liver tissue}

Spectrophotometric determination of AOPP levels was performed by modification of Witko's method (Witko et al. 1992). Samples were prepared in the following way: $400 \mu \mathrm{l}$ of sample was added to one of the tubes, while the other tube contained only $400 \mu$ l of phosphate buffer saline (PBS) solution (reagent blank). Each tube was treated with $1600 \mu \mathrm{l}$ of PBS solution. Hundred microliters of $1.16 \mathrm{~mol} / \mathrm{l}$ potassium iodide was then added to each tube, 2 min later followed by $200 \mu \mathrm{l}$ of acetic acid. The absorbance of the reaction mixture was immediately read at $340 \mathrm{~nm}$ against

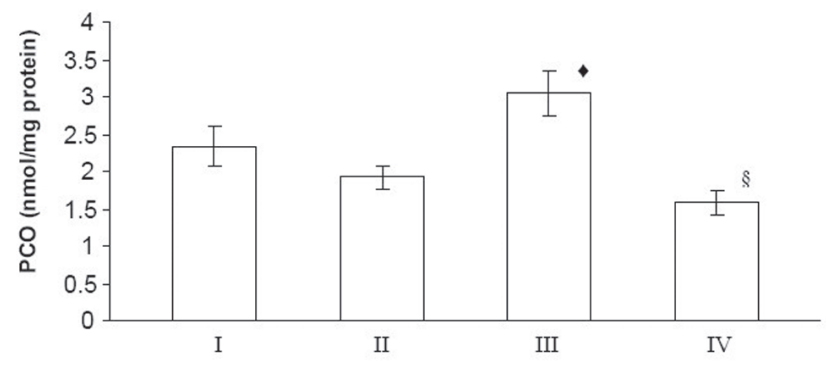

Figure 2. Effects of $50 \mathrm{~Hz}$ E field exposure $(12 \mathrm{kV} / \mathrm{m}$ for 7 days, $8 \mathrm{~h} /$ day) in protein carbonyl content (PCO) in the liver of guinea pigs. Value of means \pm SEM $(n=10)$. Groups: I, control; II, E field exposure; III, NAC; IV, NAC + E filed exposure; ${ }^{\circ} p<0.05$ (Group II vs. Group III); ${ }^{\S} p<0.05$ (Group III vs. Group IV). a blank containing $2000 \mu \mathrm{l}$ of PBS, $100 \mu \mathrm{l}$ of potassium iodide and $200 \mu \mathrm{l}$ of acetic acid. Concentrations of AOPP were calculated by using the extinction coefficient of 261 $\mathrm{mmol}^{-1} \cdot \mathrm{cm}^{-1}$.

\section{Determination of 3-NT levels in plasma}

Concentration of 3-NT was determined using commercially available enzyme-linked immunoassay (ELISA) kit from Oxiss International Inc. (USA). The calibration curve was approximately linear in the range of $2.1-1500 \mathrm{nmol} / \mathrm{l}$ when plotted on a log-linear basis. For the ELISA assay, an ELX800 absorbance microplate reader from Bio-Tek Instruments Inc. (USA) was used.

\section{Statistical analysis}

Statistical analyses were carried out using SPSS software (version 11.5 for Windows; SPSS Inc., Chicago, USA). The one-way analysis of variance (ANOVA, Bonferonni) and post hoc multiple comparison tests, Least significant difference $t$ test (LSD) were performed on the data of biochemical variables to examine the difference among groups. A $p$-value of $<0.05$ was considered as statistically significant. All data were expressed as mean \pm SEM.

\section{Results}

The results and assessment of significance are illustrated in Figures 2-5.

There is a significant change in the hydroxyproline level (Figure 5), but no significant differences were found in AOPP (Figure 2), PCO (Figure 3) and 3-NT levels (Figure 4) in electric field exposure group (Group II ) compared to the control (Group I).

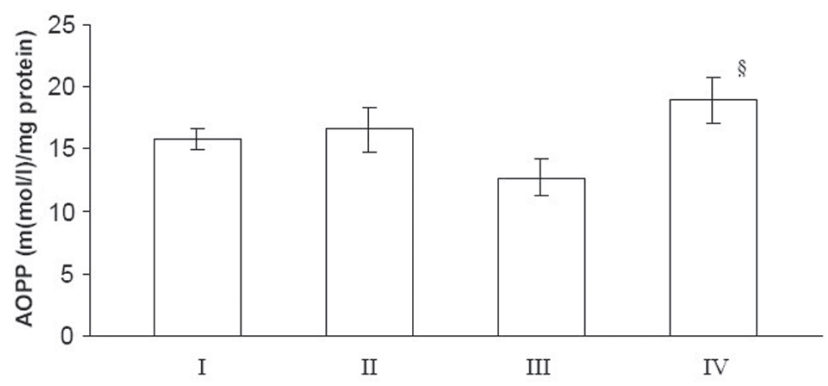

Figure 3. Effects of $50 \mathrm{~Hz}$ E field exposure $(12 \mathrm{kV} / \mathrm{m}$ for 7 days, $8 \mathrm{~h} /$ day) in advanced oxidation protein products (AOPP) in the liver of guinea pigs. Value of means \pm SEM $(n=10)$. Groups: I, control; II, E field exposure; III, NAC; IV, NAC + E filed exposure; ${ }^{\S} p<$ 0.05 (Group III vs. Group IV). 


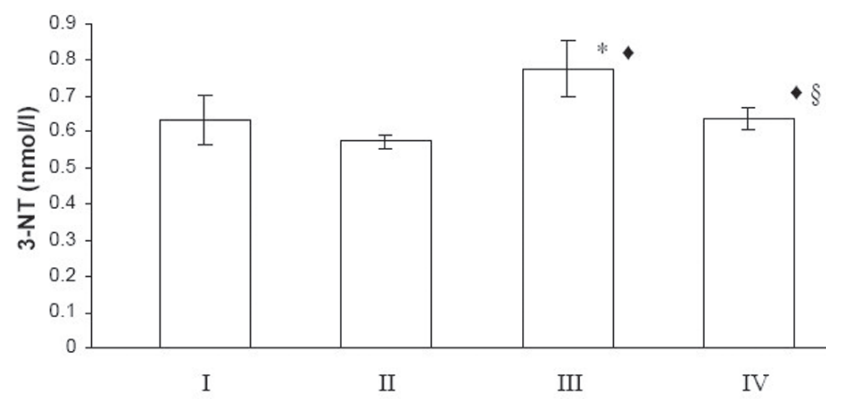

Figure 4. Effects of $50 \mathrm{~Hz}$ E field exposure $(12 \mathrm{kV} / \mathrm{m}$ for 7 days, $8 \mathrm{~h} /$ day) in 3-nitrotyrosine (3-NT) in plasma of guinea pigs. Value of means \pm SEM $(n=10)$. Groups: I, control; II, E field exposure; III, NAC; IV, NAC + E filed exposure; ${ }^{*} p<0.05$ (Group Ivs. Group III); ${ }^{*} p<0.05$ (Group II vs. Group III), IV; ${ }^{\S} p<0.05$ (Group III vs. Group IV).

Significant changes were observed in 3-NT levels in NACadministrated groups (Group III) with respect to Group I (Figure 4).

PCO, hydroxyproline and 3-NT levels were significantly changed in Group II with respect to Group III (Figures 2, 4 and 5).

Differences in hydroxyproline and 3-NT levels between Group II and NAC-administrated E field exposed group (Group IV) were significant (Figures 4 and 5). Moreover, significant differences in AOPP, PCO and 3-NT levels were observed between Group III and Group IV (Figures 2, 3 and 4).

\section{Discussion}

For many years, effects of ELF EMF have been a subject of intensive theoretical and experimental studies (Knave 2001; Hardell and Sage 2008). Wertheimer and Leeper (1979) performed the first study that found the association between childhood leukemia and residential ELF magnetic fields resulted by power lines. This link, subsequently confirmed by a number of epidemiological studies led to the classification of ELF magnetic fields by the International Agency for Research on Cancer (see in References: WHO IARC 2002) as a "possible human carcinogen". Moreover, experimental studies have reported on biological and health consequences of exposure to E fields in different directions, strengths and periods in the range of several kilovolts per milliseconds that power lines impose on people in nearby residential areas (Grandolfo and Vecchia 1985; Güler et al. 2006). A line of charges (e.g. a power line) produces an $\mathrm{E}$ field around the line in a pattern of cylindrical symmetry. The overall pattern of $E$ field experienced at any point thus depends on the distribution of charges and of objects in the vicinity. For this reason, scientists are curious about the possible effects of the E fields

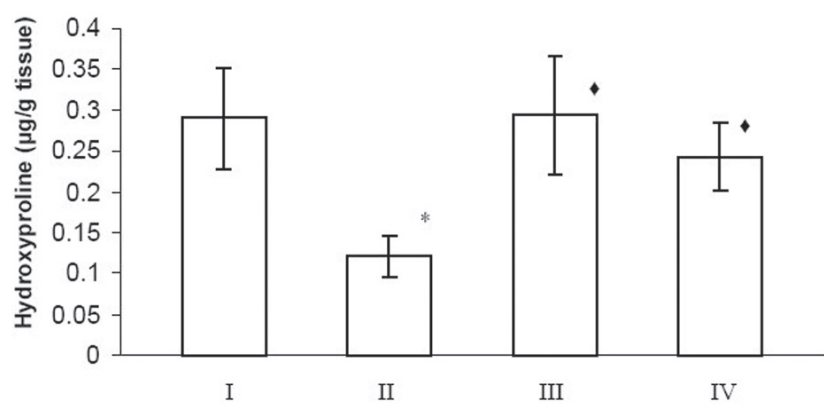

Figure 5. Effects of $50 \mathrm{~Hz}$ E field exposure $(12 \mathrm{kV} / \mathrm{m}$ for 7 days, $8 \mathrm{~h} /$ day) in hydroxyproline in the liver of guinea pigs. Value of means \pm SEM $(n=10)$. Groups: I, control; II, E field exposure; III, NAC; IV, NAC + E filed exposure; ${ }^{*} p<0.05$ (Group I vs. Group II; ${ }^{\circ} p<$ 0.05 (Group II vs. Groups III and IV).

in vertical and horizontal direction particularly on the body weight, mortality and blood protein fraction (Marino et al. 1976; 1983) beside oxidative stress (Güler et al. 2005, 2006; Harakawa et al. 2005) and collagen biosynthesis (Marino and Becker 1970; Güler and Atalay Seyhan 1996; Güler et al. 1996; Ahmadian et al. 2006).

Collagen, a significant and abundant protein, provides the framework for parenchymal organs such as the liver, kidney, and spleen, either in its fibrous form or organized in basement membranes (Ramachandran 1967). It is known that hepatic stellate cells are the main sources of collagen and other extracellular matrix proteins that ultimately lead to hepatic fibrosis and cirrhosis. Additionally, ROS enhance stellate cell activation and stimulate fibrogenesis (Nieto et al. 1999). According to studies, oxidation products such as lipid peroxidation products can stimulate a collagen expression and collagen synthesis by stellate cells in culture (Chojkier et al. 1989; Maher et al. 1994). ROS can be generated by increased nicotinamide adenine dinucleotide phosphate $(\mathrm{NAD}(\mathrm{P}) \mathrm{H})$ oxidase, which produces $\mathrm{O}_{2}{ }^{-}$from oxygen $\left(\mathrm{O}_{2}\right)$. NAD $(\mathrm{P}) \mathrm{H}$ oxidase is present in both parenchimal and non-parenchimal liver cells. Several studies indicate that NO also inhibits collagen formation as a regulatory function in many physiological processes including gene expression (Novitskiy et al. 2006).

Cell proliferation and cell migration represent important early events of angiogenesis, which involve the reorganization of actin into stress fibres and long filaments (Ridley and Hall 1992; Lauffenberg and Horwitz 1996). The effects induced by EMFs on cellular systems also include possible rearrangements of actin filaments, which take place near the membrane structure (Bersani et al. 1997; Gartzke and Lange 2002; Manni et al. 2002). Furthermore, Delle Monache et al. (2008) reported that some important functions of human microvascular endothelial cells, like proliferation, migration and tube formation are increased under the influence of a 
sinusoidal EMF. In addition to this, wound healing induced by the endogenous E field generated near skin wounds can serve as an example of cell migration (Ciombor and Aaron 2005; Nuccitelli et al. 2008). E field and EMF regulate the expression of genes in connective tissue cells for extra-cellular matrix proteins (Ciombor and Aaron 2005).

Protein damages and destructions are believed to be related to oxidative stress, mediated by ROS (Oliver et al. 1987; Sevier and Kaiser 2006; Mori et al. 2007). With the catalytic action of transition metals (iron and copper) that is bound to appropriate sites of proteins, highly reactive hydroxyl radicals $(\mathrm{OH})$ are generated and can modify nearby amino acids residues including cysteines, methionine, tryptophan, arginine, lysine, proline and histidine (Davies et al. 1987). Protein carbonylation is the result of secondary reactions of amino groups of these amino acid residues with other reactive oxidation products such as lipid peroxidation products (Barreiro et al. 2005). Ferreira et al. (2006a,b) has studied the effects of EMF on protein carbonyl groups from this point of view. However, they reported that protein carbonyl levels did not change after exposure to high frequency $(800-1800 \mathrm{MHz})$ radiation.

Biochemical characterization has revealed that AOPP are carried by plasma proteins, especially albumin. AOPP can be formed in vitro by exposure of serum albumin to hypochlorous acid. In vivo, plasma concentration of AOPP closely correlates to the levels of dityrosine, a hallmark of oxidized protein, and pentosidine, a marker of protein glycoxidation tightly related to oxidative stress. Thus, AOPP can be formed during oxidative stress by reaction of plasma proteins with chlorinated oxidants, and they have been considered as novel markers of oxidant-mediated protein damage (Liu et al. 2006). AOPP were proposed as one of the possible markers of oxidative injury, which originates under oxidative and carbonyl stress and increases global inflammatory activity. Moreover, $\mathrm{ONOO}^{-}$is a powerful oxidant agent formed by the diffusion-limited reaction between $\mathrm{NO}$ and $\mathrm{O}_{2}{ }^{-}$. At physiological $\mathrm{pH}, \mathrm{ONOO}^{-}$is capable of reacting easily with a number of molecules, such as proteins, lipids, nitrate free tyrosine and tyrosine residues in proteins to form 3-NT, which is a stable product that provides $\mathrm{ONOO}^{-}$-mediated tissue damage (Gow et al. 2004).

In conclusion, the power frequency E field did not produce a statistically significant change in the levels of PCO and AOPP of liver, also plasma level of 3-NT with respect to the control. However, it is found that hydroxyproline levels are statistically increased under the effect of ELF E field. These results may be caused by the fact that ELF E field may affect the early formation of stable oxidized protein, changing the direction of the formation reaction of oxidized proteins or leading to structural damage in protein synthesis although no statistically significant change was observed in the levels of PCO and AOPP. These suggestions have been verified by the study on the inhibition effect of ELF E fields on protein synthesis (Güler et al. 1996). Güler and co-workers investigated the changes of hydroxyproline levels in various tissues (liver, lung and kidney) via different intensities (0.9 and 1.9 $\mathrm{kV} / \mathrm{m}$ ) and alternative directions (vertical and horizontal). Exposure periods were $9 \mathrm{~h}$ /day for 3 days. They found both increased and decreased hydroxyproline levels due to the changes of the molecular oxygen concentration within tissues. Molecular oxygen could be converted to free radicals by the energy transfer from the E field to exposed tissues. Thus, the increased amounts of E field induced free radicals can lead to a decrease in the amount of the molecular oxygen needed in hydroxyproline formation in tissues.

Although protein oxidative damage in blood and liver tissue after ELF E fields has not been investigated so far, some researchers have studied high frequency radiation effects on protein oxidation. It has been shown that exposure to low durations of microwave increases $3-\mathrm{NT}$ accumulation in several tissues (Kalns et al. 2000). The enhanced formation of $\mathrm{O}_{2}{ }^{-}$and $\mathrm{NO}$ from tissue by the action of UV light has been proposed, and 3-NT levels have been demonstrated to elevate after consecutive UV light exposure in tissues (Büyükafşar et al. 2003; Cejková et al. 2005).

Our results also showed that statistical differences existed between Group IV (and Group II in plasma 3-NT levels. It may be explained by the pro-oxidative effect of NAC as reported previously by Solov'eva et al. (2007). NAC, an antioxidant and inhibitor of inducible NO synthase, has been previously demonstrated to not only restore the antioxidant capacity but also to reduce the expression of inducible NO synthase and nitrotyrosine and to normalize the expression of endothelial NO synthase in heart and superior mesenteric arteries (Nagareddy et al. 2006). Also, Reale et al. (2006) reported that EMF may regulate the reaction, which is mediated by $\mathrm{NO}$ as a secondary messenger.

It is the first study to investigate ELF E field effects on PCO, AOPP and 3-NT as well as the depressive impact of NAC treatment on these parameters under ELF E field exposure. In our further studies, we plan to investigate oxidative damages and antioxidant systems in all tissues under the application of both ELF E fields and radio frequency radiation to share with scientific community.

Acknowledgements. This work was supported by grants from Gazi University Research Foundation and ESF-COST Action B-35. We also would like to acknowledge our heart-felt thanks to Aysegul Altintas, a distinguished alumni of Yale University and a current $\mathrm{PhD}$ candidate at Sabanci University for her dedicated efforts editing of English usage and grammar of the manuscript.

\section{References}

Ahmadian S., Zarchi S. R., Bolouri B. (2006): Effects of extremelylow-frequency pulsed electromagnetic fields on collagen 
synthesis in rat skin. Biotechnol. Appl. Biochem. 43, $71-75$

Alderman C. J., Shah S., Foreman J. C., Chain B. M., Katz D. R. (2002): The role of advanced oxidation protein products in regulation of dendritic cell function. Free Radic. Biol. Med. 32, 377-385

Barreiro E., Gea J., Falco M. D., Kriazhev L., James S., Hussain S. N. A. (2005): Protein carbonyl formation in the diaphragm. Am. J. Respir. Cell Mol. Biol. 32, 9-17

Bediz C. S., Baltaci A. K., Mogulkoc R., Oztekin E. (2006): Zinc supplementation ameliorates electromagnetic field-induced lipid peroxidation in the rat brain. Tohoku J. Exp. Med. 208, 133-140

Bersani F., Marinelli F., Ognibene A., Matteucci A., Cecchi S., Santi S., Squarzoni S., Maraldi N. M. (1997): Intramembrane protein distribution in cell cultures is affected by $50 \mathrm{~Hz}$ pulsed magnetic fields. Bioelectromagnetics 18, 463-469

Blank M. (1995): EMF studies. Science 270, 1104-1105

Büyükafşar K., Levent A., Un I., Ark M., Arikan O., Ozveren E. (2003): Mediation of nitric oxide from photosensitive stores in the photorelaxation of the rabbit corpus cavernosum. Eur. J. Pharmacol. 459, 263-267

Cakatay U., Telci A., Kayalı R., Tekeli F., Akçay T., Sivas A. (2003): Relation of aging with oxidative protein damage parameters in the rat skeletal muscle. Clin. Biochem. 36, 51-55

Cejková J., Ardan T., Cejka C., Kovaceva J., Zídek Z. (2005): Irradiation of the rabbit cornea with UVB rays stimulates the expression of nitric oxide synthases-generated nitric oxide and the formation of cytotoxic nitrogen-related oxidants. Histol. Histopathol. 20, 467-473

Chojkier M., Houglum K., Solis-Herruzo J., Brenner D. A. (1989): Stimulation of collagen gene expression by ascorbic acid in cultered human fibroblasts. A role of lipid peroxidation. J. Biol. Chem. 264, 16957-16962

Ciombor D. M, Aaron R. K. (2005): The role of electrical stimulation in bone repair. Foot Ankle Clin. 10, 579-593

Cumaoglu A., Cevik C., Rackova L., Ari N., Karasu C. (2007): Effects of antioxidant stobadine on protein carbonylation, advanced oxidation protein products and reductive capacity of liver in streptozotocin-diabetic rats: role of oxidative/nitrosative stress. Biofactors 30, 171-178

Dalle-Donne I., Rossi R., Giustarini D., Milzani A., Colombo R. (2003): Protein carbonyl groups as biomarkers of oxidative stress. Clin. Chim. Acta 329, 23-38

Davies K. J. A., Delsignore M. E., Lin S. W. (1987): Protein damage and degradation of oxygen radicals: modifications of amino acids. J. Biol. Chem. 262, 9902-9907

Delle Monache S., Alessandro R., Iorio R., Gualtieri G., Colonna R. (2008): Extremely low frequency electromagnetic fields (ELF-EMFs) induce in vitro angiogenesis process in human endothelial cells. Bioelectromagnetics 29, 640-648

Ferreira A. R., Bonatto F., de Bittencourt Pasquali M. A., Polydoro M., Dal-Pizzol F., Fernández C., de Salles A. A., Moreira J. C. (2006a): Oxidative stress effects on the central nervous system of rats after acute exposure to ultra high frequency electromagnetic fields. Bioelectromagnetics 27, 487-493
Ferreira A. R., Knakievicz T., Pasquali M. A., Gelain D. P., DalPizzol F., Fernández C. E., de Salles A. A., Ferreira H. B., Moreira J. C. (2006b): Ultra high frequency-electromagnetic field irradiation during pregnancy leads to an increase in erythrocytes micronuclei incidence in rat offspring. Life Sci. 80, 43-50

Gartzke J., Lange K. (2002): Cellular target of weak magnetic fields: Ionic conduction along actin filaments of microvilli. Am. J. Physiol., Cell. Physiol. 283, 1333-1346

Gow A. J., Farkouh J. R., Munson D. A., Posencheg M. A., Ischiropoulos H. (2004): Biological significance of nitric oxide-mediated protein modifications. Am. J. Physiol., Lung Cell. Mol. Physiol. 287, 262-268

Grandolfo M., Vecchia P. (1985): Natural and man-made environmental exposures to static and ELF electromagnetic fields. In: Biological Effects and Dosimetry of Static and ELF Electromagnetic Fields. (Eds. M. Grondolfo, S. M. Michaelson and A. Rindi), pp. 49-70, Plenum Press, New York and London

Güler G., Atalay Seyhan N. (1996): Changes in hydroxyproline levels in electric field tissue interaction. Indian J. Biochem. Biophys. 33, 531-533

Güler G., Hardalaç F., Aricioğlu A. (2005): Examination of electric fields on tissues by using back propagation neural network. J. Med. Syst. 29, 679-709

Güler G., Seyhan N., Aricioğlu A. (2006): Effects of static and 50 $\mathrm{Hz}$ alternating electric fields on superoxide dismutase activity and TBARS levels in guinea pigs. Gen. Physiol. Biophys. 25, 177-193

Güler G., Seyhan Atalay N., Özoğul C., Erdoğan D. (1996): Biochemical and structural approach to collagen synthesis under electric fields. Gen. Physiol. Biophys. 15, 429-440

Güler G., Türközer Z., Seyhan N. (2007): Electric field effects on Guinea pig serum: the role of free radicals. Electromagn. Biol. Med. 26, 207-223

Halliwell B. (1997): What nitrates tyrosine? Is nitrotyrosine specific as a biomarker of peroxynitrite formation in vivo. FEBS Lett. 411, 157-160

Harakawa S., Inoue N., Hori T., Tochio T., Kariya T., Takahashi K., Doge F., Suzuki H., Nagasawa H. (2005): Effects of a $50 \mathrm{~Hz}$ electric field on plasma lipid peroxide level and antioxidant activity in rats. Bioelectromagnetics 26, 589-594

Hardell L., Sage C. (2008): Biological effects from electromagnetic field exposure and public exposure standards. Biomed. Pharmacother. 62, 104-109

Ilhan A., Gurel A., Armutcu F., Kamilsi S., Iraz M., Akyol O., Ozen S. (2004): Ginkgo biloba prevents mobile phoneinduced oxidative stress in rat brain. Clin. Chim. Acta 340, 153-162

Kalns J., Ryan K. L., Mason P. A., Bruno J. G., Gooden R., Kiel J. L. (2000): Oxidative stress precedes circulatory failure induced by $35-\mathrm{GHz}$ microwave heating. Shock 13, 52-59

Knave B. (2001): Electromagnetic fields and health outcomes. Ann. Acad. Med. Singap. 30, 489-493

Lauffenberg D. A., Horwitz A. F. (1996): Cell migration: a physically integrated molecular process. Cell 84, 359-369 
Levine R. L., Garland D., Oliver C. N., Amici A., Climent I., Lenz A. G., Ahn B. W., Shaltiel S., Stadtma E. R. (1990): Determination of carbonyl content in oxidatively modified proteins. Methods. Enzymol. 186, 464-478

Liu S. X., Hou F. F., Guo Z. J., Nagai R., Zhang W. R., Liu Z. Q., Zhou Z. M., Zhou M., Xie D., Wang G. B., Zhang X. (2006): Advanced oxidation protein products accelerate atherosclerosis through promoting oxidative stress and inflammation. Arterioscler. Thromb. Vasc. Biol. 26, $1156-1162$

Lowry O. H., Roseberg N. J., Farr A. L., Randell R. J. (1951): Protein measurement with folin phenol reagent. J. Biol. Chem. 193, 265-275

Lupke M., Rollwitz J., Simkó M. (2004): Cell activating capacity of $50 \mathrm{~Hz}$ magnetic fields to release reactive oxygen intermediates in human umbilical cord blood-derived monocytes and in mono mac 6 cells. Free Radic. Res. 38, 985-993

Maher J. J., Tzagarakis C., Gimenez A. (1994): Malondialdehyde stimulates collagen production by hepatic lipocytes only upon activation in primary culture. Alcohol Alcohol. 26, 605-610

Manni V., Lisi A., Pozzi D., Rieti S., Serafino A., Giuliani L., Grimaldi S., (2002): Effects of extremely low frequency $(50 \mathrm{~Hz})$ magnetic field on morphological and biochemical properties of human keratinocytes. Bioelectromagnetics 23, 298-305

Marino A. A., Becker R. O. (1970): The effect of electric current on rat tail tendon collagen in solution. Calcif. Tissue Res. 4, 330-338

Marino A. A., Becker R. O., Ullrich B. (1976): The effect of continious exposure to low frequency electric fields on three generations of mice: a pilot study. Experientia 32, 565-566

Marino A. A., Berger T. J., Mitchell J. T., Duhacek B. A., Becker R. (1983): Electric field effects in selected biologic systems. Ann. N. Y. Acad. Sci. 405, 436-444

Mori H., Oikawa M., Tamagami T., Kumaki H., Nakaune R., Amano J., Akinaga Y., Fukui K., Abe K., Urano S. (2007): Oxidized proteins in astrocytes generated in a hyperbaric atmosphere induce neuronal apoptosis. J. Alzheimers Dis. 11, 165-74

Nagareddy P. R., Xia Z., MacLeod K. M., McNeill J. H. (2006): Nacetylcysteine prevents nitrosative stress-associated depression of blood pressure and heart rate in streptozotocin diabetic rats. J. Cardiovasc. Pharmacol. 47, 513-520

Nieto N., Friedman S. L., Greenwel P., Cederbaum A. I. (1999): CYP2E1-mediated oxidative stress induces collagen type I expression in rat hepatic stellate cells. Hepatology 30, 987-996

Novitskiy G., Potter J. J.,Wang L., Mezey E. (2006): Influences of reactive oxygen species and nitric oxide on hepatic fibrinogenesis. Liver Int. 26, 1248-1257

Nuccitelli R., Nuccitelli P., Ramlatchan S., Sanger R., Smith P. J. (2008): Imaging the electric field associated with mouse and human skin wounds. Wound Repair Regen. 16, 432-441

Oktem F., Ozguner F., Mollaoglu H., Koyu A., Uz E. (2005): Oxidative damage in the kidney induced by $900-\mathrm{MHz}$-emitted mobile phone: protection by melatonin. Arch. Med. Res. 36, 350-355

Oliver C. N., Ahn B. W., Moerman E. J., Goldstein S., Stadtman E. R. (1987): Age-related changes in oxidized proteins. J. Biol. Chem. 262, 5488-5491

Oral B., Guney M., Ozguner F., Karahan N., Mungan T., Comlekci S., Cesur G. (2006): Endometrial apoptosis induced by a $900-\mathrm{MHz}$ mobile phone: preventive effects of vitamins E and C. Adv. Ther. 23, 957-973

Ozguner F., Altinbas A., Ozaydin M., Dogan A., Vural H., Kisioglu A. N., Cesur G., Yildirim N. G. (2005a): Mobile phoneinduced myocardial oxidative stress: protection by a novel antioxidant agent caffeic acid phenethyl ester. Toxicol. Ind. Health 21, 223-230

Ozguner F., Oktem F., Ayata A., Koyu A., Yilmaz H. R. (2005b): A novel antioxidant agent caffeic acid phenethyl ester prevents long term mobile phone exposure- induced renal impairment in rat. Mol. Cell. Biochem. 277, $73-80$

Ozguner F., Bardak Y., Comlekci S. (2006): Protective effects of melatonin and caffeic acid phenethyl ester against retinal oxidative stress in long-term use of mobile phone: a comparative study. Mol. Cell. Biochem. 282, 83-88

Pan H. Z., Zang H., Chang D., Li H., Sui H. (2008): The change of oxidative stress products in diabetes mellitus and diabetic retinopathy. Br. J. Ophthalmol. 92, 548-551

Ramachandran G. N. (1967): Treatise on Collagen. In: Biology of Collagen. Vol. 2, Academic Press, London and New York

Reale M., De Lutiis M. A., Patruno A., Speranza L., Felaco M., Grilli A., Macrì M. A., Comani S., Conti P., Di Luzio S. (2006): Modulation of MCP-1 and iNOS by $50-\mathrm{Hz}$ sinusoidal electromagnetic field. Nitric Oxide 15, 50-57

Ridley A. J., Hall A. (1992): The small GTP-binding protein rho regulates the assembly of focal adhesions and actin stress fibres in response to growth factors. Cell 70, 389-399

Sevier C. S., Kaiser C. A. (2006): Disulfide transfer between two conserved cysteine pairs imparts selectivity to protein oxidation by Ero1. Mol. Biol. Cell 17, 2256-2266

Seyhan N., Canseven A. G. (2006): In vivo effects of ELF MFs on collagen synthesis, free radical processes, natural antioxidant system, respiratory burst system, immune system activities, and electrolytes in the skin, plasma, spleen, lung, kidney, and brain tissues. Electromagn. Biol. Med. 25, 291-305

Seyhan N., Güler G. (2006): Review of in vivo static and ELF electric fields studies performed at Gazi Biophysics Department. Electromagn. Biol. Med. 25, 307-323

Simko M., Hartwig C., Lantow M., Lupke M., Mattson M.-O., Rahman Q., Rollwitz J. (2006): Hsp70 expression and free radical release after exposure to non-thermal radiofrequency electromagnetic fields and ultrafine particles in human Mono Mac 6 cells. Toxicol. Lett. 161, 73-82

Solov'eva M. E., Solov'ev V. V., Faskhutdinova A. A., Kudriavtsev A. A., Akatov V. S. (2007): Prooxidant and cytotoxic action of $\mathrm{N}$-acetylcysteine and glutathione combined with vitamin Bl2b. Tsitol. Genet. 49, 70-78 (in Russian) 
Stadtman E. R., Levine R. L. (2000): Protein oxidation. Ann. N. Y. Acad. Sci. 899, 191-208

Stadtman E. R., Levine R. L. (2003): Free radical-mediated oxidation of free amino acids and amino acid residues in proteins. Amino Acids 25, 207-218

Wertheimer N., Leeper E. (1979): Electrical wiring configurations and childhood cancer. Am. J. Epidemiol. 109, 273-284

Witko V., Nguyen A. T., Descamps-Latscha B. (1992): Microtiter plate assay for phagocyte derivered taurine-chloramines. J. Clin. Lab. Anal. 6, 47-53

WHO IARC (2002): Monographs on the evaluation of carcinogenic risks to humans. Non-ionizing radiation: I. Static and
Extremely Low Frequency (ELF) Electric and Magnetic Fields. Vol. 80, Lyon, France

Zmyslony M., Rajkowska E., Mamrot P., Politanski P., Jajte J. (2004): The effect of weak $50 \mathrm{~Hz}$ magnetic fields on the number of free oxygen radicals in rat lymphocytes in vitro. Bioelectromagnetics 25, 607-612

Zobali F., Cakici I., Karasu C. (2001): Effects of peroxynitrite on the reactivity of diabetic rat aorta. Pharmacology 63, 58-64

Received: May 18, 2008

Final version accepted: September 30, 2008 